\title{
THE USE OF LICHEN GROWTH RINGS IN LICHENOMETRY: SOME PRELIMINARY FINDINGS
}

\author{
BY \\ R.A. ARMSTRONG ${ }^{1}$ AND T. BRADWELL ${ }^{2}$ \\ ${ }^{1}$ Vision Sciences, Aston University, Birmingham, UK \\ ${ }^{2}$ British Geological Survey, West Mains Road, Edinburgh, UK
}

Armstrong, R.A., and Bradwell, T. 2010: The use of lichen growth rings in Lichenometry: some preliminary findings. Geogr. Ann., 92A (x): xx-xx.

\begin{abstract}
Certain species of crustose lichens have concentrically zoned margins which probably represent yearly growth rings. These marginal growth rings offer an alternative method of studying annual growth fluctuations, establishing growth rate-size curves, and determining the age of thalli for certain crustose species. Hence, marginal growth rings represent a potentially valuable, unexploited, tool in lichenometry. In a preliminary study, we measured the widths of the successive marginal rings in 25 thalli of Ochrolechia parella (L.) Massal., growing at a maritime site in north Wales. Mean ring widths of all thalli varied from a minimum of $1.02 \mathrm{~mm}$ (the outermost ring) to a maximum of $2.06 \mathrm{~mm}$ (the third ring from the margin). There is some suggestion that marginal ring width and thallus size are positively correlated; and hence that growth rates increase in larger thalli in this small population. In a further study on recently exposed bedrock adjacent to Breiðarlon, SE Iceland, we examined the potential for using marginal growth rings to estimate thallus age of a lichen tentatively identified as a Rhizocarpon (possibly R. concentricum (Davies) Beltram.) and thus confirm the timing of surface exposure (c. 50 years). Collectively, these results suggest: 1 ) the measurement of marginal rings is a possible alternative method of studying the growth of crustose lichens; 2) $O$. parella may grow differently to other crustose species, exhibiting a rapidly increasing radial growth rate in thalli $>40 \mathrm{~mm}$; 3) where lichens with marginal rings grow on recently exposed surfaces ( $<60 \mathrm{yrs})$, minimum age estimates can be made using growth rings as an in situ indication of lichen growth rate; 4) it is suggested that this phenomenon could provide a valuable, previously unexploited, in situ lichenometric-dating tool in areas lacking calibration control.
\end{abstract}

Key Words: Ochrolechia parella (L.) Massal., Rhizocarpon, Marginal growth ring, Radial growth rate, age-size curve, lichen-dating. 


\section{Introduction}

Certain species of crustose lichens, e.g., members of the genera Pertusaria, Lecanora, and Ochrolechia, have concentrically zoned margins. In some species, there are alternating light and dark bands at the margin - the lighter bands being interpreted as rapid summer growth and the narrow dark zones much lower growth in winter (Hale, 1973). Each 'zone' is therefore assumed to represent growth in one year and, in some thalli, growth can be traced back three to ten years.

A pioneering study of marginal zonation was carried out by Hooker (1980) in Antarctica. He found that in Buellia russa (Hue.) Darb., zonation was present only in the non-lichenised hypothallus and that each concentric zone represented one year's growth. By contrast, B. coniops (Wahlenb.) Th.Fr. and Caloplaca cirrochrooides (Vainio) Zahbr. possessed 'pseudoannual rings' with new rings encompassing two rather than one growing season. In addition, the rings of Caloplaca were not as distinct as those of the other species and no new growth rings were formed during observations of two further growing seasons.

Data on the width of the marginal rings could represent an alternative method of studying annual fluctuations in growth and the growth rate-size curve of certain crustose lichens. For such a method to be useful, however, marginal rings would need to be distinct, easily measurable with accuracy, and for each ring to actually represent one year's growth. This study presents some preliminary observations on the marginal growth rings observed in a population of Ochrolechia parella (L.) Massal. (Fig. 1) growing at a maritime site in north Wales; a species in which distinct rings are often evident at the margin.

The phenomenon of marginal rings in certain crustose species may prove to be a useful unexploited tool in lichenometry. Although no previous studies have attempted to use lichen growth rings as a proxy for age, our initial assessments suggest that certain species with cyclic, probably annual, records of growth within their structure could be used for dating purposes, akin to tree-rings (dendrochronology). Hence, this 
article also presents a small experiment using lichens with marginal growth rings to predict the age of a dated surface in southeast Iceland.

\section{Materials and Methods}

\section{North Wales study}

The study was carried out at a site in South Gwynedd, north Wales (Grid Ref. SN 6196) in an area of Ordovician slate rock (Armstrong, 1974). Slate outcrops varying in surface area from $2-30 \mathrm{~m}^{2}$ are a common feature of the hillsides in this region. These surfaces possess a rich lichen flora characteristic of siliceous rock in the north and west of the UK (James et al., 1977) and include communities with a high proportion of crustose species (Armstrong, 1974). O. parella is a member of several different communities at the site, including those on north- and south-facing rock surfaces, and rocks with steep or shallow slopes and is especially common at maritime sites (Armstrong, 1974).

Growth rings were measured on 25 randomly selected thalli of O. parella, $1.8-11.8$ $\mathrm{cm}$ in diameter, growing on maritime rocks at Aberdovey, North Wales. Each thallus was photographed using a Canon IXUS 70 digital camera, which incorporates a X12 zoom lens, and which provides a particularly clear image of the rings (Fig. 1). A scale measure marked in millimeters was also placed adjacent to each thallus. The widths of the rings were measured using a PC and 'Image' software developed by the National Institute of Health (NIH), Bethesda, USA (Available from: National Technical Information Service, Springfield, Virginia, USA). The width of each easily identifiable marginal ring was then measured at five randomly selected points around each thallus and averaged for each individual.

Data analysis was carried out using STATISTICA Software. First, the widths of the analogous marginal rings commencing with the outermost ring were averaged over all thalli and were compared using a one-way analysis of variance (ANOVA). Second, the widths of all the marginal rings measured from each thallus were averaged and 
mean width of ring plotted against thallus size to obtain information on the growth rate-size curve.

\section{Iceland study}

Fieldwork around the southern margin of Vatnajökull in Iceland identified a number of recently exposed surfaces colonized by a crustose lichen tentatively identified as a Rhizocarpon (possibly R. concentricum (Davies) Beltram.) possessing well-developed marginal rings (Fig. 2). A small study in 2009 focused on one of those surfaces and the use of concentrically zoned lichens to estimate the establishment of lichen growth and the timing of surface exposure. We briefly report these results here.

Glacially moulded striated bedrock surfaces on the southern shore of Breiðarlon were revealed from beneath the Breiðamerkerjökull outlet glacier during the second half of the $20^{\text {th }}$ century. Aerial photographs taken by the National Land Survey of Iceland in 1945 and 1965 show that the bedrock outcrop was ice covered in 1945 and ice free by 1965. Ice-front measurements made annually by the Icelandic Glaciolgical Society at the western margin of Breiðamerkerjökull (Sigurdsson, 1998) show that this glacier underwent a period of slow recession between 1945 and 1955, followed by more rapid recession from 1955 until 1965. These data also show that there have been no subsequent readvances of the ice margin across this ground. Collectively, these sources indicate that the bedrock surface on the shore of Breiðarlon has been continuously exposed since 1955 +/-5 yrs.

Long axes of the largest 5 lichen thalli were measured using a flexible transparent ruler. Digital photographs of each large thalli, with scale bars, were taken for reference, using a Canon EOS 350D (8 Megapixel camera).

\section{Results}

North Wales study

The width of each distinct marginal ring from each of the 25 thalli is shown in Table 1. All of the $O$. parella thalli exhibited at least one distinct marginal ring, 11/25 (44\%) thalli exhibited two rings, and 11/25 (44\%) thalli exhibited three or more rings. 
The maximum number of rings identified from an individual thallus was 6 from a thallus $7.5 \mathrm{~cm}$ in diameter.

The widths of the successive rings averaged over thalli are shown in Table 2. Mean width varied from a minimum of $1.02 \mathrm{~mm}$ (the outermost ring) to a maximum of 2.06 $\mathrm{mm}$ (the third ring from the margin). There was no statistically significant difference in mean widths averaged over thalli $(\mathrm{F}=1.63, \mathrm{P}>0.05)$.

A plot of mean width of the marginal rings against thallus size is shown in Fig. 3. The distribution of points is bimodal, a group of small thalli exhibiting narrow rings and the remaining larger thalli, with two exceptions, much wider rings. A linear model was fitted to the relationship between ring width and thallus size $(r=0.59, \mathrm{P}<0.01)$.

\section{Iceland study}

The largest thallus (70-mm long axis) of Rhizocarpon ?concentricum (Fig. 2) exhibited clear concentric marginal zonation or 'growth rings'. Enlarged monochrome photographs allowed six distinct growth rings to be identified - each ring comprising a dark and light coloured band. Ring widths in this large thallus typically ranged from 1-2 $\mathrm{mm}$. The central portion of the thallus ( $\sim 30 \mathrm{~mm}$ diameter) showed no evidence of ring structures.

\section{Discussion}

\section{North Wales study}

This article presents preliminary data on the widths of the marginal rings of the crustose lichen $O$. parella growing at a maritime site in north Wales. In this population, a high proportion of thalli exhibited at least two distinct growth rings with a smaller number of thalli exhibiting four or more rings. The rings were easily identifiable and measurable using a digital camera and imaging software. Rings were only evident and easily measured at the margin of the thallus and may be obscured in the more central parts of the thallus by increasing growth in thickness and by the 
formation of reproductive structures. It is possible, however, that methods of imaging thalli could be devised that might reveal the central growth rings.

The first problem in using marginal rings as a measure of growth is what does each marginal ring represent? Early studies suggested that the lighter bands represented rapid summer growth and the narrow dark bands growth in winter (Hale, 1973) and therefore, each 'zone' was assumed to represent growth in one year. The pioneering study by Hooker (1980), however, identified a more complex relationship between marginal rings and growth. In Buellia russa, for example, zonation was present only in the non-lichenised hypothallus and each concentric zone represented one year's growth. By contrast, in B. coniops and Caloplaca cirrochrooides 'pseudoannual rings' were present with new rings each encompassing two growth seasons. In addition, the rings of Caloplaca were not as distinct as those of the other species and no new growth rings were formed during two growing seasons. Hence, marginal rings cannot be assumed to represent annual growth and hence, would have to be 'validated' for $O$. parella. To validate the growth rings, a comparison would need to be made of new annual radial growth measured directly over a period of years with corresponding new growth rings that developed over the same period. It is also possible that studies of lichens of known age, and which possess growth rings, could be useful in studies of validation.

Second, if each ring does represent annual growth, the data suggest considerable variation between the widths of analogous rings in different thalli. Hence, large samples of thalli may be required before growth rings could be used as a reliable measure of annual growth fluctuations. These results suggest that local differences in microclimate over the rock surface, e.g., associated with aspect and slope variations, may be more important than overall climatic variations in determining the widths of growth rings.

Third, the data may provide some information on the growth rate-size curve in crustose lichens; a question of particular concern in the study of lichenometry. Various growth models have been proposed for the shape of the growth curve. First, Proctor (1977) studied the growth curve of the placodioid species Buellia (Diploicia) 
canescens (Dicks.) DeNot. It was assumed that radial growth rates (RGR) were proportional to an area of thallus in an annulus of constant width within the growing margin and that the shape of the growth curve was essentially asymptotic (i.e., RGR increases rapidly and then 'flattens off'). Second, a number of studies (Armstrong, 1983; Haworth, et al., 1986; Bradwell and Armstrong, 2007) have suggested that in Rhizocarpon geographicum (L.) DC., the growth curve is not asymptotic, but approximates to a second-order (parabolic) curve: RGR increasing in smaller thalli to a maximum and then declining in larger thalli. Third, Trenbirth and Matthews (in press, this volume) propose several models for the growth curve of $R$. geographicum including models in which growth increases with size, remains relatively constant or is parabolic with a declining phase. The present preliminary data provide no evidence for a declining phase of growth in O. parella, instead growth seems to be low in individuals 2-4 cm and then to increase rapidly in individuals greater than about $4 \mathrm{~cm}$ in diameter. Clearly, the problem of the shape of the growth rate-size curve in crustose lichens is far from settled and further data utilizing much larger samples will be needed to establish the growth curve of $O$. parella from marginal rings.

\section{Iceland study}

If each light-dark marginal ring of the Rhizocarpon species studied is assumed to be an annual growth increment, $8.5 \mathrm{~mm}$ of radial growth occurred in the last 5 whole years. The visible concentric rings in this thallus give a direct indication of the growth rate of this species in this environment. Simple linear extrapolation of this radial growth rate (i.e. $8.5 \mathrm{~mm}$ per 5 years) across the whole thallus indicates that this 70 mm-diameter thallus is at least 20 years old. However, it is well documented that growth rates of juvenile crustose thalli $(<10 \mathrm{~mm})$ are significantly slower than those of more established thalli (>10 mm) (e.g. Proctor 1977; Armstrong 1983, 2005; Benedict 2008). Thus a minimum age estimate for this lichen thallus may be closer to 30 years. In addition, empirical studies have shown that colonization of clean abraded rock surfaces in southern Iceland takes in the region of 15-25 years, depending on a range of micro-environmental factors (Gordon and Sharp 1983; Maizels and Dugmore 1985; Bradwell 2001). This minimum surface-age estimate $(30+20$ yrs = AD 1959) is consistent with the known exposure age of the glacially-abraded bedrock surface at Breiðarlon (AD 1955+/-5). 
This small experimental study has shown that marginal lichen growth rings, if assumed to be annual, could be used as a tool in lichenometry to inform age estimations, when information on lichen growth history and colonization times are available. We propose that marginal rings in certain crustose species (e.g. species of Pertusaria, Ochrolechia, Rhizocarpon etc.) can give a useful in situ indication of lichen growth rates. This in turn could be used to estimate lichen ages, and hence surface exposure ages, most notably in areas where growth-rate calibration curves cannot be constructed.

\section{Conclusions}

This small study draws the following conclusions:

1) The measurement of marginal rings, present in certain crustose species, offers a possible alternative method of studying the growth rate of lichens.

2) O. parella may grow differently to other crustose species, exhibiting a rapidly increasing radial growth rate in thalli $>40 \mathrm{~mm}$.

3) Growth rings can be used to inform lichen age estimations. A pilot study using a species of Rhizocarpon growing on a 55-year-old surface adjacent to Brieðamerkurjökull in Iceland, shows that lichen age can be estimated using marginal (annual) growth rings, coupled with a knowledge of lichen growth history and colonization times. We propose that marginal rings could therefore provide a valuable, previously unexploited, lichenometric-dating tool in areas lacking calibration control.

\section{Acknowledgements}

We thank Mark Garnett and an anonymous reviewer for their helpful comments on the manuscript. TB publishes with the permission of the Executive Director, BGS (NERC). 
Dr R.A. Armstrong, Vision Sciences, Aston University, Birmingham B4 7ET, UK, Email: R.A.Armstrong@aston.ac.uk

Dr Tom Bradwell, British Geological Survey, Murchison House, West Mains Road, Edinburgh, EH9 3LA, UK

Email:tbrad@bgs.ac.uk

\section{References}

Armstrong, R.A., 1974: The descriptive ecology of saxicolous lichens in an area of South Merionethshire, Wales. Journal of Ecology, 62: 33-45.

Armstrong, R.A., 1983: Growth curve of the lichen Rhizocarpon geographicum. New Phytologist, 94: 619-622.

Armstrong, R.A., 2005: Growth curves of four crustose lichens. Symbiosis, 38: 45-57.

Benedict, J.B., 2008: Experiments on lichen growth. III. The shape of the age-size curve. Arctic, Antarctic and Alpine Research, 40: 15-26.

Bradwell, T., 2001: Glacier fluctuations, lichenometry and climatic change in Iceland. Unpublished PhD thesis, University of Edinburgh: 365pp.

Bradwell, T. and Armstrong, R.A., 2007: Growth rates of Rhizocarpon geographicum lichens: a review with new data from Iceland. Journal of Quaternary Science, 22: 311-320.

Gordon, J.E. and Sharp, M., 1983: Lichenometry in dating recent glacial landforms and deposits, southeast Iceland. Boreas 12, 191-200.

Hale, M.E., 1973: Growth. In: The Lichens. Ahmadjian V and Hale ME (eds). Academic Press, New York, pp 473-492.

Haworth, L.A., Calkin, P.E. and Ellis, J.M., 1986: Direct measurement of lichen growth in the central Brooks Range, Alaska USA and its application to lichenometric dating. Arctic and Alpine Research, 18: 289-296. 
Hooker, T.N., 1980: Lobe growth and marginal zonation in crustose lichens. Lichenologist, 12: 313-323.

James, P.W., Hawksworth, D.L. and Rose, F., 1977: Lichen communities in the British Isles: A preliminary conspectus. In: Seaward, M.R.D. (ed.) Lichen Ecology, pp. 295-419, Academic Press, New York.

Maizels, J.K. and Dugmore, A.J., 1985: Lichenometric dating and tephrochronology of sandur deposits, Sólheimajökull area, southern Iceland. Jökull, 35: 69-77.

Proctor, M.C.F., 1977: The growth curve of the crustose lichen Buellia canescens (Dicks) De Not. New Phytologist, 79: 659-663.

Sigurðsson, O., 1998: Glacier variations in Iceland 1930-1995. Jökull, 45: 3-26.

Trenbirth, H.E. and Matthews, J.A., 2010: Lichen growth rates on glacier forelands in southern Norway: preliminary results from a 25-year monitoring programme. Geografiska Annaler (in press). 
Table 1. The widths of marginal growth rings in a sample of thalli of the crustose lichen Ochrolechia parella (L.)Massal. growing at a maritime site in north Wales. Rings are measured in sequence from the margin towards the centre of the thallus.

\begin{tabular}{|c|c|c|c|}
\hline$\underline{\text { Thallus }}$ & $\underline{\text { Thallus diameter (mm) }}$ & $\begin{array}{l}\text { Width of marginal rings } \\
\underline{(\mathrm{mm})}\end{array}$ & $\frac{\text { Mean width }}{\underline{(\mathrm{mm})}}$ \\
\hline 1 & 37 & $0.3,0.1$ & 0.20 \\
\hline 2 & 39 & 0.2 & 0.20 \\
\hline 3 & 22 & $0.4,0.2$ & 0.30 \\
\hline 4 & 30 & 0.3 & 0.30 \\
\hline 5 & 44 & $0.7,0.5,0.6,0.6,0.6$ & 0.60 \\
\hline 6 & 36 & 0.2 & 0.20 \\
\hline 7 & 74 & $0.5,0.6$ & 0.55 \\
\hline 8 & 115 & $1.2,1.0,1.5,1.0,1.4$ & 1.22 \\
\hline 9 & 45 & $0.1,0.5$ & 0.30 \\
\hline 10 & 67 & $2.4,2.0,2.0,3.0$ & 2.35 \\
\hline 11 & 75 & $2.1,2.1,2.0,1.0,2.0,1.1$ & 1.72 \\
\hline 12 & 48 & $1.4,2.0,1.2$ & 1.53 \\
\hline 13 & 36 & $0.4,0.2,0.3$ & 0.30 \\
\hline 14 & 33 & $0.3,0.5$ & 0.40 \\
\hline 15 & 38 & $0.2,0.4$ & 0.30 \\
\hline 16 & 38 & $0.3,0.7$ & 0.50 \\
\hline 17 & 30 & $0.2,0.5$ & 0.35 \\
\hline 18 & 62 & $2.2,1.6,1.6,1.8$ & 1.80 \\
\hline 19 & 28 & $2.0,1.0$ & 1.50 \\
\hline 20 & 66 & $2.8,2.0,2.1,1.5,2.2$ & 2.10 \\
\hline 21 & 35 & $2.0,1.9,1.6$ & 1.83 \\
\hline 22 & 54 & $2.0,1.8,2.2,2.0$ & 2.00 \\
\hline 23 & 118 & $2.9,2.5,2.2,2.0$ & 2.40 \\
\hline 24 & 50 & $0.6,0.3$ & 0.45 \\
\hline 25 & 18 & $0.4,0.3$ & 0.35 \\
\hline
\end{tabular}


Table 2. Mean diameter of successive growth rings (standard errors in parentheses), averaged over thalli, in a sample of thalli of the crustose lichen Ochrolechia parella (L.)Massal. growing at a maritime site in north Wales. Rings are measured from the margin (1) towards the centre of the thallus (6).

Marginal ring

\begin{tabular}{llllll}
\hline 1 & 2 & 3 & 4 & 5 & 6 \\
\hline 1.02 & 1.03 & 2.06 & 1.61 & 1.87 & 1.10 \\
$(0.18)$ & $(0.17)$ & $(0.43)$ & $(0.27)$ & $(0.24)$ & - \\
\hline
\end{tabular}

Analysis of variance: Between growth rings $\mathrm{F}=1.63(\mathrm{P}>0.05)$ 


\section{Figure captions}

Figure 1 Marginal rings in Ochrolechia parella (L.)Massal. thalli, growing at a maritime site in north Wales.

Figure 2 Thallus of a species tentatively identified as Rhizocarpon (possibly $R$. concentricum (Davies) Beltram.) growing on a glacially abraded bedrock outcrop adjacent to Breiðarlon, southeast Iceland. This rock surface was exposed c. 1955 according to aerial photographs and ice-front measurements. Note the well developed concentric marginal rings, numbered 1 to 6 in the SW sector. The minimum age of this thallus is estimated by extrapolation of a linear growth rate, derived directly from the marginal ring widths.

Figure 3 The relationship between mean width of growth rings and thallus size in the crustose lichen Ochrolechia parella (L.) Massal. at a maritime site in north Wales (Pearson's ' $\mathrm{r}$ ' $=0.59, \mathrm{P}<0.01$ ). 


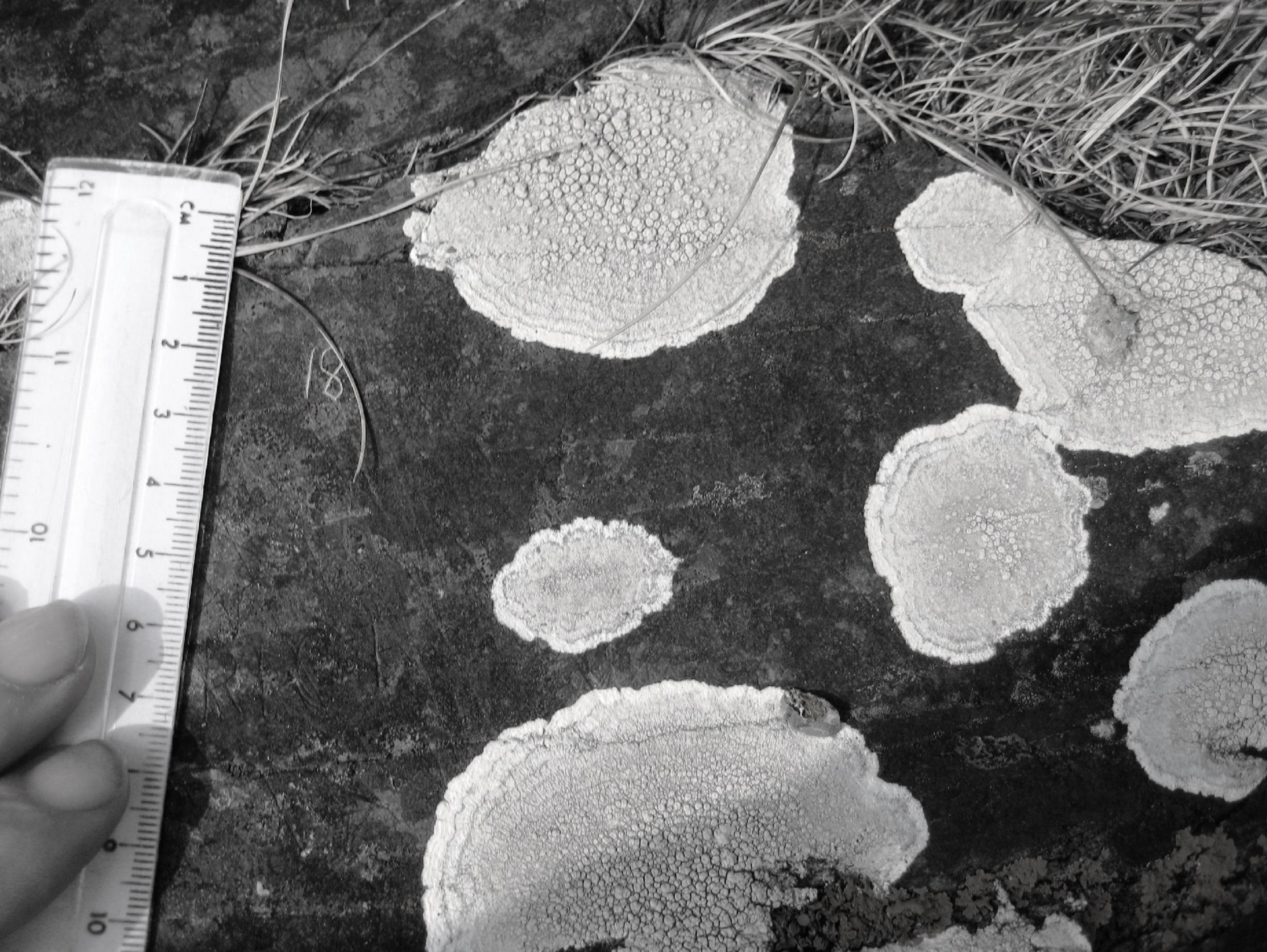




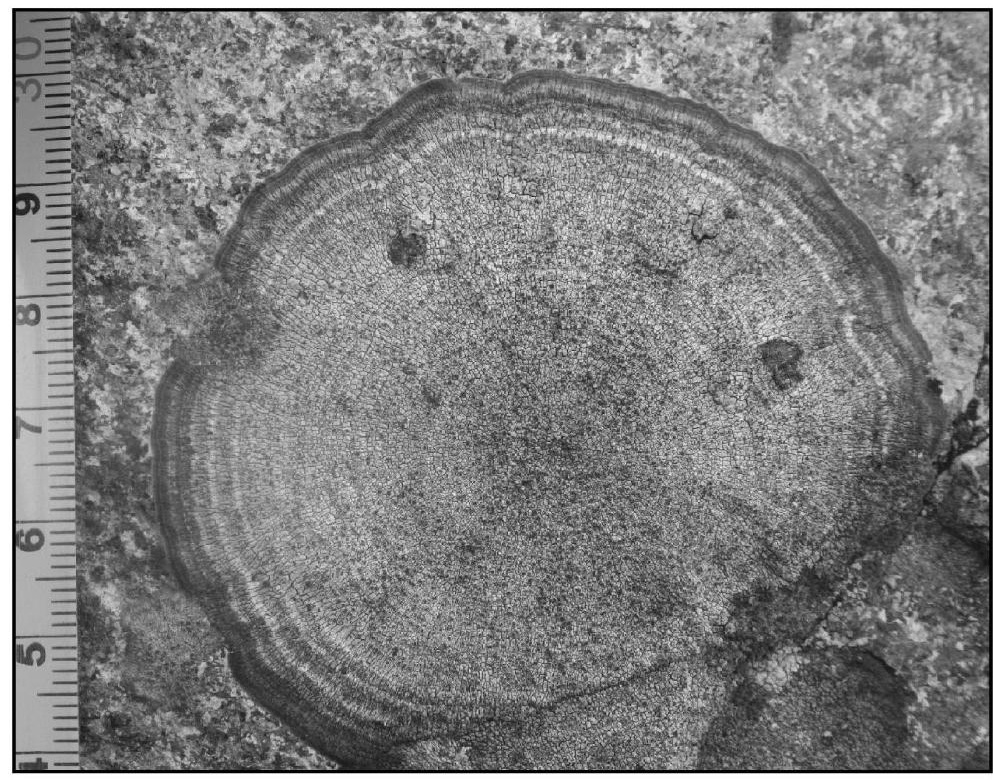




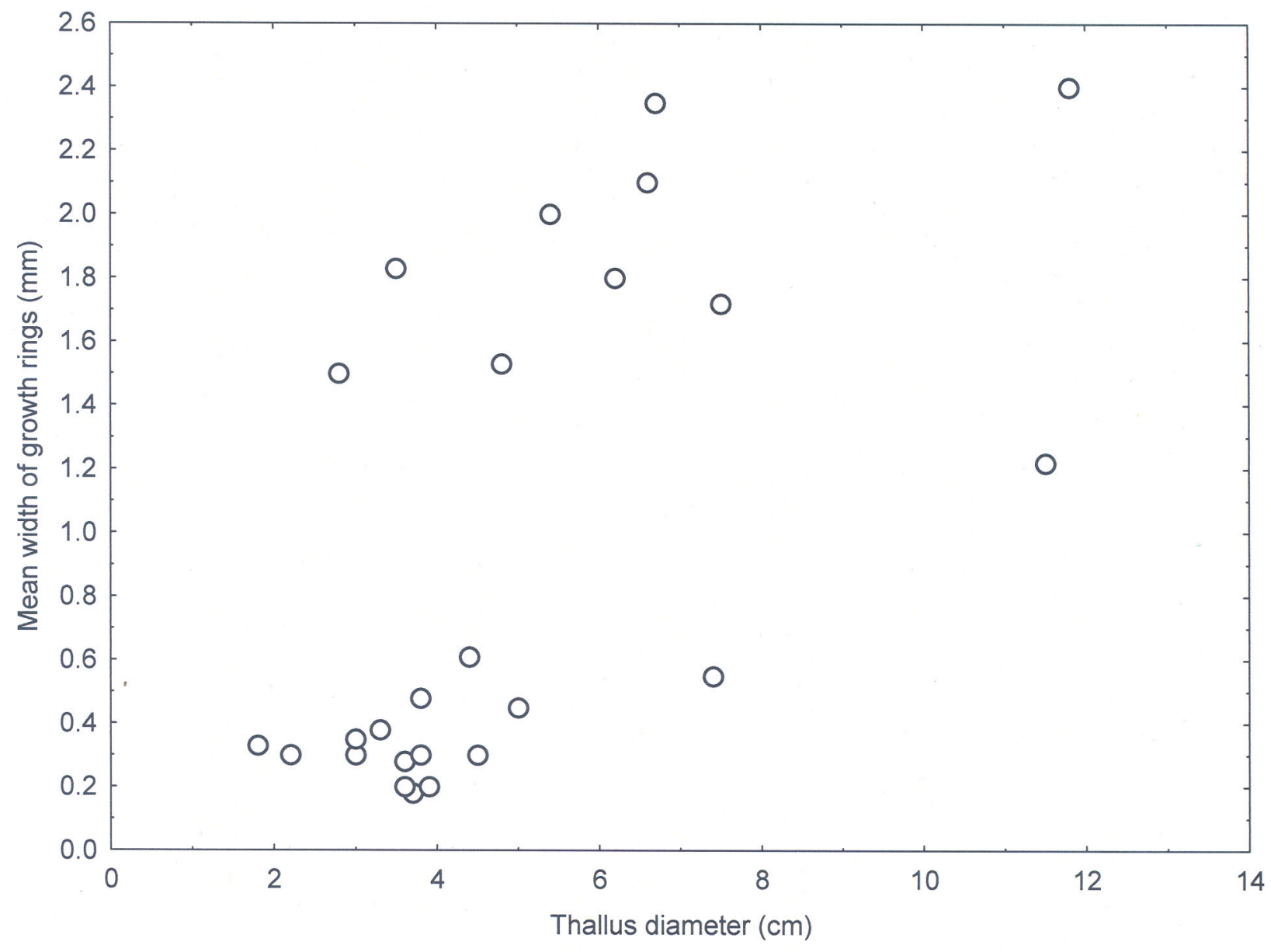

